\title{
Green ear yield and grain yield of maize after harvest of the first ear as baby corn
}

\author{
Paulo Sérgio Le Silva ${ }^{1}$; Paulo Igor B e Silva ${ }^{1}$; Ana Karenina F de Sousa ${ }^{1}$; Kamila M Gurgel ${ }^{1}$; Israel A \\ Pereira Filho ${ }^{2}$ \\ ${ }^{1}$ UFERSA, C. Postal 137, 59625-900 Mossoró-RN; ${ }^{2}$ Embrapa Milho e Sorgo, C. Postal 151, 35701-970 Sete Lagoas-MG; E-mail: \\ paulosergio@ufersa.edu.br; israel@cnpms.embrapa.br
}

\begin{abstract}
Baby corn (BC) consists of the corn ear harvested two or three days after silk emergence. $\mathrm{BC}$ is a profitable crop, making possible a diversification of production, aggregation of value and increased income. Removing the first female inflorescence induces corn to produce others, making possible to produce several $\mathrm{BC}$ ears or, alternatively, BC (by harvesting the first ear) and green ears or grain. The objective of this work was to evaluate green ear yield and grain yield, after harvesting the first ear as BC. Corn cultivar AG 1051 was submitted to the following treatments, in a random block design with ten replicates ( 52 plants per plot): $\mathrm{BC}$ harvesting; green ear harvesting (grain moisture content between 60 and 70\%); mature ear harvesting; $\mathrm{BC}$ harvesting and harvesting of other ears as green or mature ears. Marketable green ears yield or grain yield produced without removing the first inflorescence were superior to the green ears yield or grain yield produced after removal of the first inflorescence harvested as baby corn. Harvesting only the first ear as baby corn, and then harvesting green ears or the mature ears, provided lower baby corn yields than that obtained by harvesting all ears as baby corn. Economically, the best net revenues would be obtained by exploring the crop for the production of green ears, green ears + baby corn, baby corn, baby corn + grain, and grain, in this order.
\end{abstract}

Keywords: Zea mays, green corn, flowering.

\section{RESUMO}

Rendimentos de espigas verdes e de grãos de milho após a colheita da primeira espiga como minimilho

O minimilho (MM) é a espiga do milho colhida dois a três dias após a emergência dos estilo-estigmas. O MM é rentável e propicia diversificação da produção, agregação de valor e ampliação de renda. A remoção da primeira inflorescência feminina induz o milho a produzir outras. Isso possibilita a produção de várias espigas de MM ou, alternativamente, MM (colhendo-se a primeira espiga) e espigas verdes ou grãos. O objetivo do trabalho foi avaliar os rendimentos de espigas verdes e de grãos, após a colheita da primeira espiga como MM. A cultivar AG 1051 foi submetida aos seguintes tratamentos, no delineamento de blocos ao acaso com dez repetições (52 plantas por parcela): colheita de MM; colheita das espigas verdes (grãos com teor de umidade de 60 a $70 \%$ ); colheita das espigas maduras; colheita de MM e colheita das outras espigas como espigas verdes ou maduras. Os rendimentos de espigas verdes comercializáveis e de grãos, produzidos sem a remoção da primeira inflorescência, foram superiores aos rendimentos respectivos produzidos após a remoção da primeira inflorescência, colhida como minimilho. Colhendo-se somente a primeira espiga como minimilho e as demais espigas como espigas verdes ou maduras obtiveram-se menores rendimentos de minimilho que o obtido colhendo-se todas as espigas como minimilho. Economicamente, as melhores receitas líquidas seriam obtidas explorando-se a cultura para a produção de espigas verdes, espigas verdes + minimilho, minimilho, minimilho + grãos e grãos, nesta ordem.

Palavras-chave: Zea mays, milho verde, floração.

\section{(Recebido para publicação em 18 de fevereiro de 2005; aceito em 3 de maio de 2006)}

$\mathrm{C}$ orn (Zea mays L.) intended for "green corn" and grain production is one of the most important crops in the Brazilian Northeast. "Green corn" is the name given to ears harvested when the grain moisture content is between 70 and $80 \%$.

Baby corn consists of the husked ear, harvested two or three days after silk emergence. Baby corn is a profitable crop, and the growing allows for a diversification of production, aggregation of value, and increased income. Several factors influence baby corn yield, including cultivar, sowing season, planting density, detasseling, weed control, and fertilizers. As a product, it was only important in Thailand and a few other countries (Thakur et al., 1998; Carvalho et al., 2002; Pandey et al., 2002a; Pandey et al., 2002b).

Brazil has a promising market because the demand for baby corn is on the rise and the Brazilian production is nearly null (Rodrigues et al., 2004). There is also a perspective for exporting to other markets, especially those that already import a variety of Brazilian vegetable products (Hardoim et al., 1982). In view of this, some studies have been undertaken in many regions of
Brazil (Pereira Filho et al., 1998; Carvalho et al., 2002; Tomé, 2002). Farmers would substantially increase their net income by selling baby corn. (Hardoim et al., 2002).

It would be interesting, therefore, to evaluate baby corn yield under the conditions found in the Brazilian Northeast. In this region, the production of corn takes on a special significance because, as long as water is available for irrigation, production can be carried out during nearly all year and therefore during the off season in some regions.

The support provided by the state and federal governments to irrigation 
agriculture in the Brazilian Northeast allows corn to be grown during the off season and has also allowed fruticulture to become regionally important. Irrigated fruticulture, in turn, has encouraged corn cropping, since the melon plant (Cucumis melo L.), the main vegetable crop species explored by producers, is only grown in the absence of rains in order to yield better quality fruits. In the first semester of the year, fruit producing companies successfully explore corn in the areas previously occupied by melon plants, in order to produce green ears, grain, and stubble (above-ground plant parts, without ears), under dryland conditions, and where irrigation is possible. Under these conditions, another option to explore corn would be the production of baby corn.

Some cultivars of corn are prolific, and they yield more than one ear per stalk. In addition, removing the first ear induces the plant to produce new inflorescences (Silva, 2001). This characteristic makes it possible to produce several baby corn ears or, alternatively, baby corn (by harvesting the first ear) and green ears or grain (in the second ear). The objective of this work was to evaluate green ear yield and corn grain yield, after harvesting the first ear as baby corn.

\section{MATERIAL AND METHODS}

The experiment was carried out at Experimental Farm 'Rafael Fernandes' (experimental farm), of the Universidade Federal Rural do SemiÁrido (UFERSA), located $20 \mathrm{~km}$ away from the municipal seat of Mossoró, RN, Brazil ( $5^{\circ} 11^{\prime} \mathrm{S} ; 37^{\circ} 20^{\prime} \mathrm{W}$, and 18 $\mathrm{m}$ altitude), during the period from August to November, 2003. The climate information data for the region were summarized by Carmo Filho \& Oliveira (1989). The analysis of a soil sample from the experimental area, a "Argissolo Vermelho-Amarelo Eutrófico", according to the Brazilian Soil Classification System (EMBRAPA, 1999), and Ferric Lixisol, according to the Soil Map of the World (FAO, 1988), indicated: $\mathrm{pH}\left(\mathrm{H}_{2} \mathrm{O}\right)=6.5 ; \mathrm{Ca}=1.19$; $\mathrm{Mg}=0.97 ; \mathrm{K}=0.15 ; \mathrm{Na}=0.22 ; \mathrm{Al}=0.00$;
$\mathrm{H}+\mathrm{Al}=0.49 ; \mathrm{SB}=2.53 ; \mathrm{CEC}=3.02$; and $\mathrm{t}=2.53 \mathrm{cmol} \mathrm{dm}_{\mathrm{c}}^{-3} ; \mathrm{m}=0.00 \%, \mathrm{~V}=83.8 \%$; $\mathrm{P}=2.0 \mathrm{mg} \mathrm{dm}^{-3}$; organic $\mathrm{C}=0.48 \%$; Org. Matter $=1.90 \mathrm{~g} \mathrm{~kg}^{-1}$. Further details on the experimental soil have been presented by Mota (2004).

Corn cultivar AG 1051, a short sized, super-early double hybrid with yellow dent grain, was submitted to the following treatments; harvest of baby corn ears, at the time of female flowering; harvest of green ears, when the grain showed a moisture content varying between 60 and $70 \%$; harvest of mature ears, after physiological maturation, when the grain showed a moisture content of approximately $20 \%$; harvest of the first female inflorescence as baby corn and later harvests of other ears formed as green ears; harvest of the first female inflorescence as baby corn and later harvests of other ears formed as mature ears.

A random block design with ten replicates was utilized. Each experimental unit consisted of four 6.0 $\mathrm{m}$ long rows. The usable area was considered as the space occupied by the two central rows, with the elimination of plants from one pit at each end.

The soil was tilled by means of two harrowings. The plots were identified and received $30 \mathrm{~kg} \mathrm{~N}$ (ammonium sulfate), $\quad 60 \quad \mathrm{~kg} \quad \mathrm{P}_{2} \mathrm{O}_{5} \quad$ (single superphosphate), and $30 \mathrm{~kg} \mathrm{~K}_{2} \mathrm{O}$ (potassium chloride) per hectare, in furrows with a depth of $10 \mathrm{~cm}$ located alongside and below the seeding furrow. Sowing was done manually at a $5 \mathrm{~cm}$ depth and a row spacing of $1.0 \mathrm{~m} \times 0.4$ $\mathrm{m}$, using four seeds $\mathrm{pit}^{-1}$. A thinning operation was performed 20 days after sowing, leaving the two more vigorous plants in each pit. Therefore, after thinning the experiment showed a population density equivalent to 50 thousand plants $\mathrm{ha}^{-1}$. The experiment was sprinkler-irrigated. The water depth required for corn $(5.6 \mathrm{~mm})$ was calculated considering an effective depth of $0.40 \mathrm{~m}$ in the root system. Irrigation time was based on the water retained by the soil at a tension of 0.04 Mpa. An irrigation shift of one day was established.

Weed control was performed by two hoeings, conducted at 20 and 45 days after sowing. Pest control was performed by means of two deltamethrin sprays $\left(250 \mathrm{ml} \mathrm{ha}^{-1}\right)$, at 7 and 14 days after sowing. After each weeding operation, the experiment was fertilized with $30 \mathrm{~kg} \mathrm{~N} \mathrm{ha}^{-1}$ (ammonium sulfate).

In baby corn, the total number and weight of ears and the number and weight of marketable ears, either unhusked or husked were evaluated. Marketable unhusked ears were considered those free from damage caused by pests or diseases, and marketable husked ears were those with good health showing a color varying from pearly white to light yellow, cylindrical in shape, with a diameter ranging from 0.8 to $1.8 \mathrm{~cm}$ and length ranging from 4.0 to $12.0 \mathrm{~cm}$. In green corn, the number and weight of marketable green ears, either unhusked or husked were evaluated. Marketable unhusked ears were considered as those with a length above $22.0 \mathrm{~cm}$ and suitable appearance for commercialization, without blemishes or perforations by pests. Marketable husked ears were considered as those with a length above $17.0 \mathrm{~cm}$ that displayed grain set and health suitable for commercialization. Next, the ears were husked and left to dry in the sun for approximately 72 hours, when they were threshed by hand. After weighing the grain, a $100 \mathrm{~g}$ sample was taken to estimate moisture content. Based on the moisture content thus determined, grain weight was corrected to a moisture content of $15.5 \%$. The number of grains per ear was estimated based on 20 ears, and the 100-grain weight was estimated based on five samples of 100 grains. After harvesting the dry ears, all plants in the usable area of each plot were used to evaluate plant height (distance from the soil level to the insertion point of the highest leaf blade) and ear height (distance from the soil level to the insertion point of the first ear).

The data were submitted to analysis of variance and the means were compared by Tukey test up to a $5 \%$ probability value using the SAEG software package (Ribeiro Júnior, 2001).

The economic analysis of the data consisted in calculating the operating income (net revenue), by subtracting the 
total cost from the gross revenue (Vasconcelos et al., 2002). The total cost was obtained by adding the fixed and variable costs. We considered as fixed cost the labor supplied by a property manager plus the depreciation, maintenance and conservation, insurance and interest on the fixed capital represented by implements (irrigation system and back-pack sprayer). variable cost included labor spent on management practices, consumables (fertilizers, etc), machinery and implement rental (harrowing and grooving operations), electric energy for irrigation, technical assistance and "PROAGRO" (both 2\% of the variable cost value) and interest on the working capital (6\% APR of the variable cost). The prices of baby corn, green corn and grain were obtained at supermarkets.

\section{RESULTS AND DISCUSSION}

Harvesting only the first ear as baby corn, and then harvesting green ears or the grain, provided lower values than those obtained in plots where all ears produced were harvested as baby corn, for all characteristics evaluated in baby corn ears (Table 1). This superiority ranged from 47 percentage points (total number or marketable unhusked ears) to 50 percentage points (number and weight of marketable husked ears). The superiority was obviously due to the corn's ability to produce new female inflorescences as the first inflorescences were removed. In treatments where green or mature ears were harvested later, starting at 69 days after planting, the proportion of baby corn ears harvested gradually decreased until becoming practically nil at 78 days after planting (Table 1). In commercial plantings, the number of baby corn harvests generally is not as many as were performed in the present work. We chose to harvest baby corn in the plots where only baby corn would be harvested, until the date when the last baby corn ears were harvested in plots where green or mature ears would be harvested later. The baby corn yields were substantially lower than those obtained by other authors (Pereira Filho et al., 1998; Pandey et al., 2002), because the planting densities used to produce

Table 1. Number and weight of baby corn ears of maize cultivar AG 1051. Mossoró, UFERSA, 2003.

\begin{tabular}{|c|c|c|c|c|}
\hline \multirow[b]{2}{*}{ Baby corn ear characteristics ${ }^{1}$} & \multicolumn{3}{|c|}{ Treatments } & \multirow[b]{2}{*}{$\begin{array}{l}\text { CV } \\
(\%)\end{array}$} \\
\hline & Baby corn & $\begin{array}{c}\text { Baby corn } \\
+ \text { green } \\
\text { ears2 }\end{array}$ & $\begin{array}{l}\text { Baby corn } \\
+ \text { mature } \\
\text { ears } 3\end{array}$ & \\
\hline Total number of ears ha ${ }^{-1}$ & 113,970 a & $48,767 \mathrm{~b}$ & $48,721 \mathrm{~b}$ & 17 \\
\hline Total ear weight $\left(\mathrm{kg} \mathrm{ha}^{-1}\right)$ & $5,441 \mathrm{a}$ & $2,434 b$ & $2,413 b$ & 27 \\
\hline Number of marketable unhusked ears ha-1 & $113,970 \mathrm{a}$ & $48,767 \mathrm{~b}$ & $48,721 b$ & 17 \\
\hline Weight of marketable unhusked ears $\left(\mathrm{kg} \mathrm{ha}^{-1}\right)$ & 5,441 a & $2,434 \mathrm{~b}$ & $2,345 b$ & 27 \\
\hline Number of marketable husked ears ha- ${ }^{-1}$ & 90,852 a & $44,871 \mathrm{~b}$ & $46,652 b$ & 17 \\
\hline Weight of marketable husked ears (kg ha-1) & $831 \mathrm{a}$ & $421 \mathrm{~b}$ & $417 \mathrm{~b}$ & 20 \\
\hline Days after planting & \multicolumn{4}{|c|}{ Proportions of harvested ears (\%) } \\
\hline 57 & 0.1 & 0.2 & 0.6 & \\
\hline 58 & 0.0 & 1.0 & 0.0 & \\
\hline 59 & 0.8 & 2.7 & 1.9 & \\
\hline 62 & 5.0 & 11.3 & 11.6 & \\
\hline 64 & 2.9 & 9.6 & 8.3 & \\
\hline 65 & 8.3 & 15.5 & 16.5 & \\
\hline 66 & 7.0 & 13.4 & 11.8 & \\
\hline 69 & 18.0 & 26.2 & 20.2 & \\
\hline 70 & 9.1 & 8.4 & 11.0 & \\
\hline 71 & 11.5 & 5.2 & 8.1 & \\
\hline 73 & 9.8 & 3.3 & 5.0 & \\
\hline 76 & 11.5 & 2.5 & 3.9 & \\
\hline 78 & 16.0 & 0.7 & 1.1 & \\
\hline
\end{tabular}

${ }^{1}$ For each baby corn ear characteristic, means followed by a common letter do not differ among themselves by Tukey test ( $\mathrm{P} \mathrm{d}$ " 0.05$)$

${ }^{2}$ Harvest of the first inflorescence as baby corn and later harvest of green ears

${ }^{3}$ Harvest of the first inflorescence as baby corn and later harvest of mature ears

exclusively baby corn may exceed 200 thousand plants ha ${ }^{-1}$ (Pereira Filho et al., 1998). Obviously, such densities could not have been used in the present work, since green ear yield and grain yield were also evaluated.

The yield superiority, in number and weight of green ears produced without removal of the first inflorescence could have been due to the fact that part of the inflorescences, formed after removal of the first inflorescence, may have never been pollinated or may have been only partially pollinated, due to its delayed formation (Table 2). Deficiencies in pollination might have occurred because of the dynamic of pollen release in corn. This dynamic tends to follow the Gauss curve, i.e., the amount of released pollen grains increases with time and then decreases after reaching maximum values (Lizaso et al., 2003). Thus, inflorescences formed at later times would have smaller chances to be pollinated because pollen availability would be reduced. Possibly the prevailing weather conditions during the flowering period, particularly relative humidity and temperature, have aggravated the reduction in pollination. Hot and dry environments cause a reduction in the viability of pollen grains (Purseglove, 1972). However, there were no differences between ears harvested with or without removal of the first ear harvested as baby corn, with regard to green ear length or diameter.

Based on the data for the total number of ears produced (Table 3 ) it is estimated that the proportion of nonpollinated ears would be around $24 \%$ of the total ears produced, without harvesting the first ear as baby corn. Possibly the reduction in green ear weight is also associated to a reduction in the number of grain ear-1, which was not evaluated in green ears, but was estimated in mature ears. In this case, some ovules of some ears would not have been pollinated because enough pollen grains were not available. The ovaries of late-fertilized ovules 
Table 2. Number, weight, length and diameter of green corn ears of maize cultivar AG 1051. Mossoró, UFERSA, 2003.

\begin{tabular}{|c|c|c|c|}
\hline \multirow[b]{2}{*}{ Evaluated characteristics ${ }^{1}$} & \multicolumn{2}{|c|}{ Ears production } & \multirow[b]{2}{*}{$\begin{array}{l}\text { CV } \\
(\%)\end{array}$} \\
\hline & $\begin{array}{c}\text { Without } \\
\text { removing the } \\
\text { first } \\
\text { inflorescence }\end{array}$ & $\begin{array}{l}\text { After removing } \\
\text { the first } \\
\text { inflores cence } \\
\text { (baby corn) }\end{array}$ & \\
\hline Number of marketable unhusked ears ha ${ }^{-1}$ & $45,874 \mathrm{a}$ & $26,470 \mathrm{~b}$ & 23 \\
\hline Weight of marketable unhusked ears $\left(\mathrm{kg} \mathrm{ha}^{-1}\right)$ & 10,584 a & $5,450 \mathrm{~b}$ & 30 \\
\hline Number of marketable husked ears ha-1 & 43,830 a & $18,789 \mathrm{~b}$ & 22 \\
\hline Weight of marketable husked ears $\left(\mathrm{kg} \mathrm{ha}^{-1}\right)$ & 6,817 a & $3,327 \mathrm{~b}$ & 24 \\
\hline Diameter of marketable husked ears $(\mathrm{cm})$ & $4.13 \mathrm{a}$ & $4.24 \mathrm{a}$ & 12 \\
\hline Length of marketable husked ears $(\mathrm{cm})$ & $12.31 \mathrm{a}$ & $12.69 \mathrm{a}$ & 4 \\
\hline Harvest dates (days after planting) & \multicolumn{3}{|c|}{ Proportions of harves ted ears (\%) } \\
\hline 73 & 40 & 21 & - \\
\hline 76 & 29 & 16 & - \\
\hline 80 & 31 & 63 & - \\
\hline
\end{tabular}

${ }^{1}$ For each characteristic evaluated, means followed by a common letter do not differ among themselves by Tukey test (P d" 0.05$)$

Table 3. Means for grain yield and the main components of this yield in maize cultivar AG 1051. Mossoró, UFERSA, 2003.

\begin{tabular}{lccc}
\hline & \multicolumn{2}{c}{ Ears production } & \\
\cline { 2 - 3 } Evaluated characteristics & $\begin{array}{c}\text { Without removing } \\
\text { the first } \\
\text { inflorescence }\end{array}$ & $\begin{array}{c}\text { After removing the } \\
\text { first inflores cence }\end{array}$ & CV (\%) \\
\hline Grain yield $\left(\mathrm{kg} \mathrm{ha}^{-1}\right)$ & $5,532 \mathrm{a}$ & $2,869 \mathrm{~b}$ & 10 \\
Number ears ha & $49,237 \mathrm{a}$ & $37,551 \mathrm{~b}$ & 12 \\
Number grain ear-1 & $416 \mathrm{a}$ & $269 \mathrm{~b}$ & 16 \\
100-grain weight $(\mathrm{g})$ & $28.5 \mathrm{a}$ & $30.5 \mathrm{a}$ & 13 \\
\hline
\end{tabular}

${ }^{1}$ For each characteristic evaluated, means followed by a common letter do not differ among themselves by Tukey test (P d" 0.05)

Table 4. Fixed, variable, and total costs, gross and net income, and margin on sales (obtained by making total cost $=100 \%$ ) for different corn purposes. Mossoró, UFERSA, 2003.

\begin{tabular}{|c|c|c|c|c|c|c|}
\hline \multirow{3}{*}{ Exploration purpose } & \multicolumn{3}{|c|}{ Costs } & \multicolumn{2}{|c|}{ Income } & \multirow{3}{*}{$\begin{array}{c}\text { Margin } \\
\text { on sales } \\
(\%)\end{array}$} \\
\hline & Fixed & Variable & Total & Gross ${ }^{1}$ & Net & \\
\hline & \multicolumn{5}{|c|}{$R \$ 1.00$} & \\
\hline Baby corn & 117 & 2,944 & 3,061 & 8,310 & 5,249 & 172 \\
\hline Green ears (GE) & 146 & 4,512 & 4,659 & 10,223 & 5,564 & 119 \\
\hline Grain (G) & 149 & 2,728 & 2,876 & 3,319 & 443 & 15 \\
\hline Baby corn + GE & 137 & 3,530 & 3,667 & 9,201 & 5,534 & 151 \\
\hline Baby corn $+G$ & 157 & 3,038 & 3,195 & 5,891 & 2,696 & 84 \\
\hline
\end{tabular}

${ }^{1}$ Assumptions: baby corn bought by the supermarket at R $\$ 10.00 / \mathrm{kg}$ (sold at R\$17.00/kg), husked and packaged green corn bought by the supermarket at $\mathrm{R} \$ 1.50 / \mathrm{kg}$ (sold at $\mathrm{R} \$ 2.00$ / $\mathrm{kg}$ ), and dry grain bought and packaged by the supermarket at $\mathrm{R} \$ 0.60 / \mathrm{kg}$ (sold at $\mathrm{R} \$ 0.80 / \mathrm{kg}$ ).

frequently abort, reducing the formation of grain (Carcova et al., 2000; Anderson et al., 2004).

The grain yield superiority (of about $48 \%$ ) in plants that were not submitted to first inflorescence removal was due to higher numbers of ears ha ${ }^{-1}$ and grain ear ${ }^{-1}$, since both treatments did not differ as to their 100-grain weight (Table 3).

Plant height $(143 \mathrm{~cm})$ and ear height $(71 \mathrm{~cm})$ were not affected by treatments. The pollination period in corn lasts, on average, from 5 to 8 days and is characterized by an interruption of stalk growth in height (Fornasieri Filho, 1992).
The fixed and variable costs are different for the different finalities of crop exploration (Table 4). The value of some taxes, which comprise fixed costs, is higher in products with a higher total income. Similarly, there are differences in variable costs between products because, for example, some of them demand more labor to be obtained. Economically, under the conditions here evaluated, corn as a crop would be more advantageous if explored for the production of green ears, followed by the production of green ears + baby corn, and finally of baby corn alone. The smallest net revenues would be achieved by exploring the crop for the production of grain or grain + baby corn. Some values presented in the economic analysis possibly are overestimated. However, several results here obtained are in agreement with those from other authors. Fixed costs contributed much smaller shares of total cost. Also, the fixed component that contributed the highest percentage was machinery and equipment depreciation, as observed by other authors (Vasconcelos et al., 2002). With regard to variable costs, the greatest contributions came from input and labor, similarly as results obtained by Vasconcelos et al. (2002). With reference to income, some authors (Hardoim et al., 2002) have presented data estimating the margin on baby corn sales as $412 \%$. It is important to point out that planting densities different from the one adopted in the present work $\left(50,000\right.$ plants ha $\left.^{-1}\right)$ must certainly result in benefits that are different from those herein obtained. This is relevant in the case of baby corn, which, as previously mentioned, is explored at planting densities higher than 200,000 plants ha1, but could be important for other products as well. Furthermore, herbage exploitation (above-ground part of the plant after harvesting the ears) has not been considered in this work. All these alternatives generate a wide range of exploration possibilities for corn.

Marketable green ears or grain yield, produced without removing the first inflorescence, were superior, to the green ears yield or grain yield produced after removal of the first inflorescence harvested as baby corn. Harvesting only the first ear as baby corn and then 
harvesting green ears or the mature ears provided lower baby corn yields than that obtained by harvesting all ears as baby corn. Economically, the best net revenues would be obtained by exploring the crop for the production of green ears, green ears + baby corn, baby corn, baby corn + grain, and grain, in this order.

\section{REFERENCES}

ANDERSON SR; LAUER MJ; SCHOPER JB SHIBLES RM. 2004. Pollination timing effects on kernel set and silk receptivity in four maize hybrids. Crop Science 44: 464-473.

CÁRCOVA J; URIBELARREA M; BORRÁS L; OTEGUI ME; WESTGATE ME. 2000. Synchronous pollination within and between ears improves kernel set in maize. Crop Science 40: 1056-1061.

CARMO FILHO F; OLIVEIRA OF. 1989. Mossoró: um município do semi-árido nordestino. Mossoró: Fundação Guimarães Duque. (Coleção Mossoroense, Série B, n. 672). 62 p.

CARVALHO GS; PINHO R; PEREIRA FILHO IA. 2002. Efeito do tipo de cultivar, despendoamento das plantas e da época de semeadura na produção de minimilho. Revista Brasileira de Milho e Sorgo 1: 47-58.
EMBRAPA. 1999. Centro Nacional de Pesquisa do Solo. Sistema brasileiro de classificação de solos. Brasília: Serviço de Produção de Informação. 412p.

FAO. 1988. Soil map of the world; revised legend. Rome: UNESCO 119p.

FORNASIERI FILHO D. 1992. A cultura do milho. Jaboticabal: FUNEP. 273p.

HARDOIM PR; SANDRI E; MALUF WR. 2002. Como fazer minimilho para aumentar a renda no meio rural. Lavras: UFLA. (Boletim Técnico de Hortaliças no. 72). 4p.

LIZASO JI; WESTGATE ME; BATCHELOR WD; FONSECAA. 2003. Predicting potential kernel set in maize from simple flowering characteristics. Crop Science 43: 892-903.

MOTA JCA. 2004. Caracterização física, química e mineralógica, como suporte para o manejo, dos principais solos explorados com a cultura do melão na Chapada do Apodi - RN . 2004. Fortaleza: UFC. 96p. (Dissertação).

PANDEY AK; MANI VP; PRAKASH V; SINGH RD; GUPTA HS. 2002a. Effect of varieties and plant densities on yield, yield attributes and economics of baby corn (Zea mays). Indian Journal of Agronomy 47: 221-226.

PANDEY AK; PRAKASH V; GUPTA HS. 2002b. Effect of integrated weed-management practices on yield and economics of baby corn (Zea mays). Indian Journal of Agricultural Sciences 72: 206-209.
PEREIRA FILHO IA; GAMA EEG; CRUZ JC. 1998. Minimilho: efeito de densidade de plantio e cultivares na produção e em algumas características da planta de milho. Sete Lagoas: EMBRAPA-CNPMS. 6p. (EMBRAPACNPMS. Pesquisa em Andamento, 23).

PURSEGLOVE JW.1972. Tropical crops. I. Monocotyledons. New York: John Wiley. $334 \mathrm{p}$.

RIBEIRO JÚNIOR JI. 2001. Análises estatísticas no SAEG. Viçosa: UFV. 301p.

RODRIGUES LRF; SILVA N; MORI ES. 2004. Avaliação de sete famílias $S_{2}$ prolíficas de minimilho para a produção de híbridos. Bragantia 63.

SILVA PSL. 2001. Desfolha e supressão da frutificação em milho. Revista Ceres 48: 1-16.

THAKUR DR; PRAKASH O; KHARWARA PC; BHALLA SK.1998. Effect of nitrogen and plant spacing on yield, nitrogen uptake and economics in baby corn (Zea mays). Indian Journal of Agronomy 43: 668-671.

TOMÉ PHF. 2002. Avaliação de cultivares de milho normal, doce e pipoca, visando o processamento mínimo de minimilho. Lavras: UFLA. 89p. (Tese).

VASCONCELOS RC; PINHO RG; REIS RP; LOGATO ES.2002. Estimativa dos custos de produção de milho na safra agrícola 1998/1999 no município de Lavras-MG. Ciência e Agrotecnologia 26: 283-291. 